\title{
Mechanism of the cathode current collector on cell performance in a solid oxide fuel cell stack
}

\author{
Wanbing Guan ${ }^{\mathrm{a} *}$, Guoliang Wang ${ }^{\mathrm{a}}$, Xiao-Dong Zhou ${ }^{\mathrm{b}}$ \\ ${ }^{a}$ Ningbo Institute of Material Technology and Engineering, Chinese Academy of Science \\ 1219 Zhongguan West Road, Zhenhai District, CN-315201, Ningbo, P. R. China \\ ${ }^{\mathrm{b}}$ Department of Chemical Engineering, University of South Carolina, 541, Main St. Columbia, SC, 29208
}

\begin{abstract}
In this work, we report a new design of the contact layer to investigate the significance and mechanism for the cathodic current collection. The single cells in a stack are covered with Ag paste on the cathode side, which exhibit slightly higher power density than that of the cell partially covered with Ag paste. The Ag paste is applied as a current-collecting layer on the cathode side at the corresponding position in contact with the punctuate structure of the interconnect. The difference in power densities between the two single cells is due to the in-plane electron transfer on the cathode surface. When the structure of the interconnect is changed from a convex punctuate structure to liner strips, the cell performance is governed by both gas flow rate and in-plane electron transfer; however, the latter plays a more important role than the gas flow rate. An appropriate arrangement of current collection at the cathode side is necessary to improve current collection and thus the cell performance inside the SOFC stack.
\end{abstract}

Keywords: Electron transfer, Interface, Contact, Stack, Solid oxide fuel cell

\footnotetext{
* Corresponding author: Tel. 86-754-86324656

Email addresses: guanwanbing@gmail.com(W.B. Guan)
} 


\section{Introduction}

The commercialization of solid oxide fuel cells (SOFCs) which directly convert chemical energy to electricity and heat, is highly dependent on the activity and durability of SOFC stacks [1].The stack repeating unit (SRU) of SOFCs consists of two interconnects, multiple sealants and a single cell. The latter, a single cell, is comprised of a cathode current collector, active cathode, electrolyte, anode, and anode current collector [2-4]. Cell materials and structure can then be optimized to improve its performance and durability to meet the requirements of various applications. For instance, new electrode materials [5-8] and nanostructures [9-11] have been reported, which resulted in a maximum power density $\geq 2.9$ $\mathrm{W} \cdot \mathrm{cm}^{-2}$ at $650^{\circ} \mathrm{C}$ with humidified $3 \% \mathrm{H}_{2}$ as fuel and air as oxidant. On the contrary, the power density of an SOFC stack is generally less than $0.6 \mathrm{Wcm}^{-2}$ [12-15], which determined by the contact layer between the cathode and the interconnect [16-20]. Because of the high-temperature oxidation atmosphere at the cathode side, researchers initially attempted to print noble metal slurry on the cathode as a current collector [21-23]. The electron collection is highly effective, and high performance can be obtained using this method. Contact resistance is reduced and cell performance is improved when noble metal slurry is coated on the cathode side. Jiang et al. found that the cell resistance decreased from $1.43 \Omega \cdot \mathrm{cm}^{-2}$ to 0.19 $\Omega \cdot \mathrm{cm}^{-2}$. The corresponding cell performance increased from $0.13 \mathrm{~W} \cdot \mathrm{cm}^{-2}$ to $0.52 \mathrm{~W} \cdot \mathrm{cm}^{-2}$ as the contact area increased from $4.6 \%$ to $27.2 \%$ by using a silver mesh as the current collector [18]. This observation showed that the increased contact area significantly improved the cell performance.

Recently, it was found that improving cell performance was not only related to the contact area but also to the contact structure [24]. If the contact area was fixed, Liu et al. reported that the smaller span of the electron collection of the interconnect tip resulted in a lower contact resistance [24]. Their observations provided evidence on the complex electron transfer on the cathode side: not only out-of-plane transfer, but also the possibility of in-plane 
electron transfer. Our previous research showed that the deeper the interconnect tip immersed into the cathode current collecting layer, the more the cell performance improved [25]. These observations suggested the existence of in-plane electron transfer in the cathode layer, which was consistent with the sheet resistance studies [26-28]. So far, much of the work was carried out by using button cells, as a result, it remains uncertain how the cathode current collector influence the cell performance in an SOFC stack when a metallic interconnect is used. Here, we utilized an anode-supported planar cell to study the effects of surface conductivity on cell performance by using a new design of contact interface.

\section{Experimental procedures}

An anode-supported cell of NiO-YSZ/YSZ/LSCF was adopted in this work. Tape casting was used to prepare NiO-YSZ anode-supported substrate with a thickness of $\sim 120$ $\mu \mathrm{m}$, which comprised of 56 wt\% high-purity NiO (>99.99\%; Sinopharm Chemical Reagent Co. Ltd. Of Shanghai) and 44 wt.\% YSZ (3YSZ; Tosho Corp., Japan). The total thickness of the laminated anode support was $\sim 500 \mu \mathrm{m}$. A $10-\mu \mathrm{m}$ thick functional anode of NiO-YSZ (8YSZ; TOSOH Corp., Japan) and 8YSZ electrolyte with ratio of 56:44 in mass were then sprayed on the anode support, followed by sintering at $1350{ }^{\circ} \mathrm{C}$ with a heating rate of about $1 \sim 2^{\circ} \mathrm{C} / \mathrm{min}$. Subsequently, a $10-\mu \mathrm{m}$ thick barrier layer of Gd-doped ceria (GDC) was sprayed on the electrolyte layer, followed by sintering at $1150{ }^{\circ} \mathrm{C}$ with a heating rate of about $2 \sim 3^{\circ} \mathrm{C} / \mathrm{min}$. Finally, a 30- $\mu \mathrm{m}$ thick cathode $\left(\mathrm{La}_{0.8} \mathrm{Sr}_{0.2} \mathrm{Co}_{0.2} \mathrm{Fe}_{0.8} \mathrm{O}_{3}, \mathrm{LSCF}\right)$ was sprayed on the GDC surface layer, followed by sintering at $1050^{\circ} \mathrm{C}$ with a heating rate of about $3 \sim 5^{\circ} \mathrm{C} / \mathrm{min}$. The cross image of the cell can be found in our previous publication [29]. The area of the substrate used in this work was $100 \mathrm{~cm}^{2}$ with an active cathode area of $63 \mathrm{~cm}^{2}$.

A contact structure for the current collection between the cathode and interconnect was designed to investigate the electron transfer paths. SUS 430 ferritic steel was chosen as the interconnect. The same batch of single cells were used to minimize the possibility of 
irreproducibility. A $50-\mu \mathrm{m}$ thick slurry of LSCF was printed on the active cathode as the cathode current collector. Two single cells were then coated with Ag paste by screen printing on the cathode side; one was completely covered (single cell 1; Fig. 1a) and the other was only covered at the points in contact with the interconnect tip (single cell 2; Fig. 1b). A schematic of the corresponding interconnect and its surface convex squares is presented in Fig. 1c. The area of the interconnect tip contacting with the cathode current collector accounted for $\sim 40 \%$ of the total cathode area.

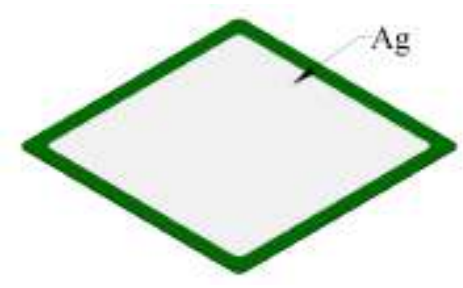

(a)

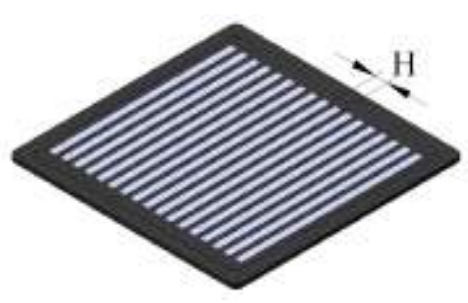

(d)

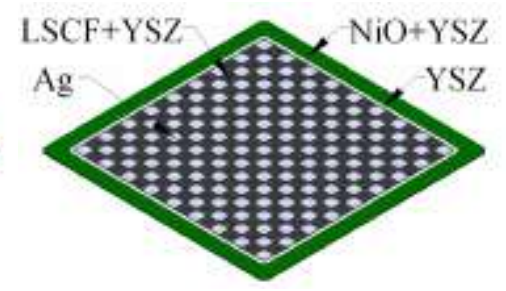

(b)

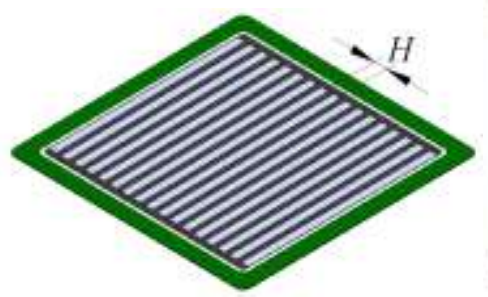

(e)

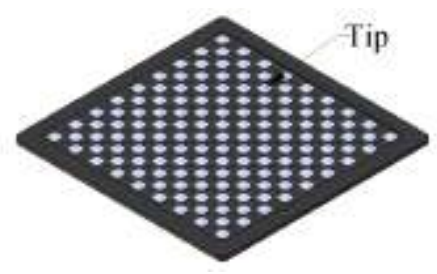

(c)

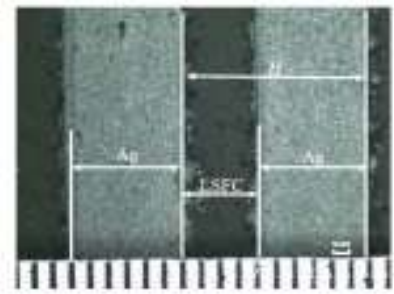

(f)

Fig. 1. Schematics of single cell and interconnect. (a) Cathode was completely covered with the Ag paste, (b) cathode was partially covered with Ag paste, (c) A schematic of the interconnect, (d) Interconnect with strips and (e) A single cell covered with Ag strips, and (f) A top surface image of the LSFC-based single cell covered with $\mathrm{Ag}$ paste showing the width of $\mathrm{Ag}$ strips and width of the parameter $\mathrm{H}$.

The structure of the interconnect tip was then changed from the convex square to strips (Fig. 1d) to further investigate the electron transfer path by changing the designs of the current-collecting structure of an interconnect. The spacing between each two strips on the cathode side was named $H$, which consists of one strip and one gas channel. The width of one strip is 1.5 times of that of one gas channel. In this study, the magnitude of $H$ was 4,6 , and 10 $\mathrm{mm})$. The spacing of the strips on the anode side remained unchanged to prevent the anode 
from affecting cell performance. After designing the cathode structure, screen printing was used to coat Ag slurry onto a position at the cathode side of the single cell, which bonds with the interconnect strips (Fig. 1e). Three single cells were screen printed with Ag paste, covering the whole area of the cathode side, named cell\# 3, 4, and 5. And another three pieces of single cells (cell\# 6, 7, and 8) was partially coated with Ag paste according to changeable $H(H=4,6$, and $10 \mathrm{~mm})$, respectively. Table I lists all the parameters for the cells and interconnects studied in this work. A stack then was assembled with cells 3, 4, 5, 6, 7, and 8 .

Fig. 1f) presents the representative surface morphology of cathodes of cells 6,7 , and 8 , the white part is the Ag slurry zoon, and the gray section is the LSCF.

Table 1 Parameters of various cells and its corresponding stacks

\begin{tabular}{|c|c|c|c|c|c|}
\hline \multirow{2}{*}{ Cells } & \multirow{2}{*}{ Stack } & \multirow{2}{*}{$\begin{array}{c}\text { Interconnect } \\
\text { surface }\end{array}$} & \multicolumn{2}{|c|}{ Designed spacing } & \multirow{2}{*}{$\begin{array}{l}\text { Ag covering on cell } \\
\text { cathode }\end{array}$} \\
\hline & & & Anode side & Cathode side & \\
\hline Cell 1 & \multirow{2}{*}{ Stack1 } & Square(Point) & $4.0 \mathrm{~mm} \times 4.0 \mathrm{~mm}$ & $4.0 \mathrm{~mm} \times 4.0 \mathrm{~mm}$ & Totally \\
\hline Cell2 & & Square(Point) & $4.0 \mathrm{~mm} \times 4.0 \mathrm{~mm}$ & $4.0 \mathrm{~mm} \times 4.0 \mathrm{~mm}$ & Partially \\
\hline Cell3 & \multirow{6}{*}{ Stack2 } & Strips & $2.4 \mathrm{~mm}$ & $2.4 \mathrm{~mm}$ & Totally \\
\hline Cell4 & & Strips & $3.6 \mathrm{~mm}$ & $2.4 \mathrm{~mm}$ & Totally \\
\hline Cell5 & & Strips & $6.0 \mathrm{~mm}$ & $2.4 \mathrm{~mm}$ & Totally \\
\hline Cell6 & & Strips & $2.4 \mathrm{~mm}$ & $2.4 \mathrm{~mm}$ & Partially \\
\hline Cell7 & & Strips & $3.6 \mathrm{~mm}$ & $2.4 \mathrm{~mm}$ & Partially \\
\hline Cell8 & & Strips & $6.0 \mathrm{~mm}$ & $2.4 \mathrm{~mm}$ & Partially \\
\hline
\end{tabular}

Cells 1 and 2 were assembled into stack 1, and cells 3, 4, 5, 6, 7, and 8 were assembled into stack 2. Detailed parameters of cells and interconnect are listed in Table I. The stack assembly process and characterization method were reported in our previous publications [30-32]. The stack was discharged and $I-V$ curves were obtained. Finally, Solartron 
$1287 / 1260$ was applied to obtain EIS curves with frequency from $10 \mathrm{mHz}$ to $100 \mathrm{KHz}$ and voltage of $20 \mathrm{mV}$. The potential between each probe was analyzed, providing a reference for the optimization of the current collection and improvement of cell performance.

\section{Results and Discussion}

Fig. 2 a) shows the $I-V$ curves for two cell units in stack 1, which consists of a full cell with two neighboring pieces of interconnect at $750{ }^{\circ} \mathrm{C}$ and $\mathrm{H}_{2} /$ air $=8 / 24 \mathrm{sccm} \mathrm{cm}^{-2}$. The maximum power density for the repeating units 1 and 2 was 0.4 and $0.3 \mathrm{~W} \cdot \mathrm{cm}^{-2}$, respectively. After discharging, the top surface image of single cells 1 and 2 was obtained by using an optical microscope. Fig. 2b) and c) shows that the boundaries of cathode contact for cells \#1 and 2 can be clearly distinguished. Based on our previous results [17], the difference in power density between repeating units 1 and 2 is mainly due to the difference in electron transfer resistance at the cathode side.
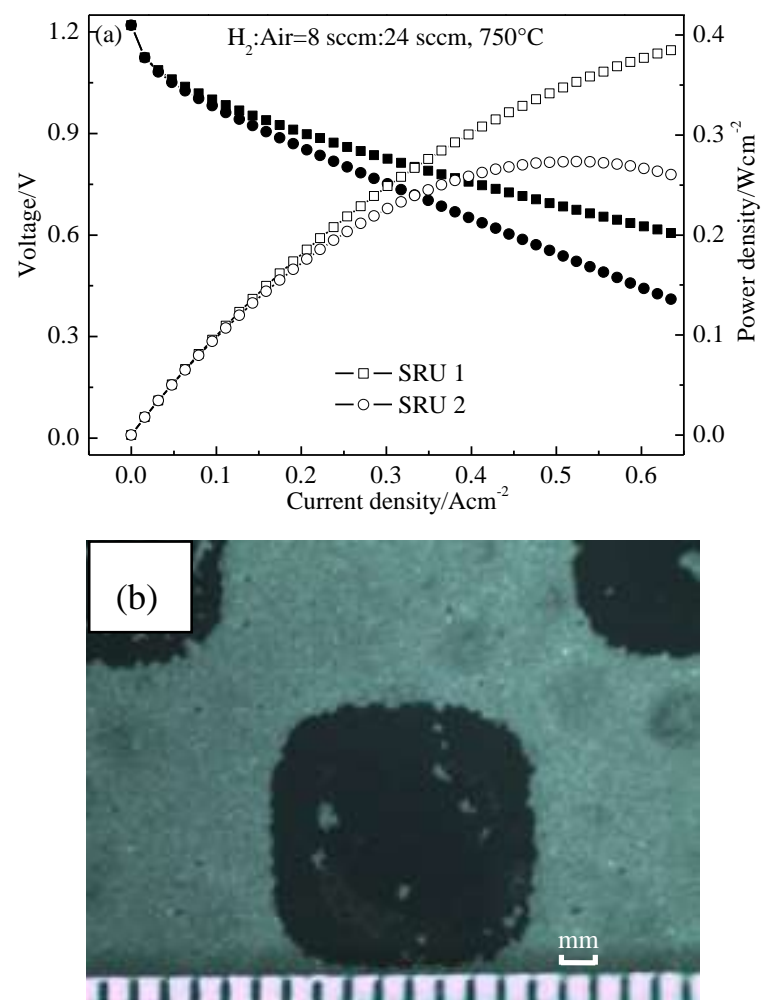

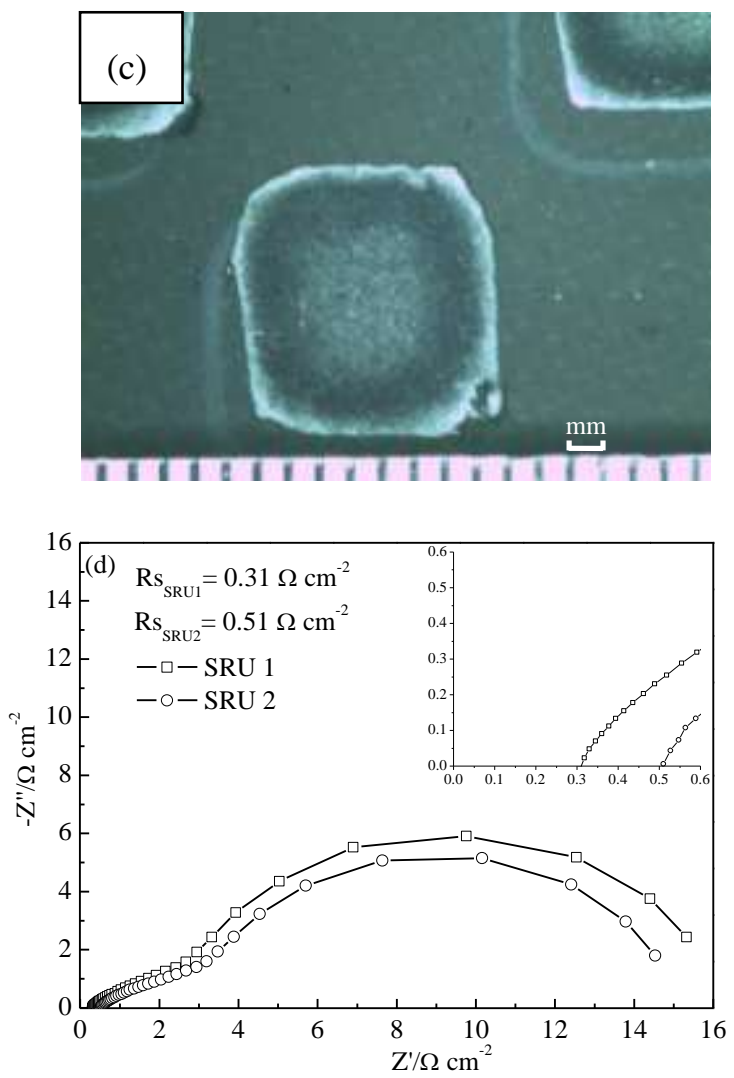

Fig. 2. $I-V$, EIS curves of stack repeating units of the stack 1 and optical images of the boundaries for the cathode current collector of single cells 1 and 2. (a) I-V curves, (b) Single cell 1 (completely covered with $\mathrm{Ag}$ ) and (c) Single cell 2 (partially covered with $\mathrm{Ag}$ ) and (d) EIS spectra of stack repeating units 1 and 2 of stack 1.

The EIS spectra obtained under open circuit voltage (OCV) conditions are shown in Fig. 2d). The ohmic resistance of stack repeating unit 2 was $60 \%$ more than that of stack repeating unit 1 . The polarization resistance of stack repeating unit 2 was slightly lower than that of the unit 1 . This result indicates that the single cell performance in a stack configuration is highly dependent on its total ohmic resistance, dominated by the electron transfer resistance under various cathode current collectors.

According to the operation principles of SOFCs and schematics of stacks [33], the in-plane electron transfer resistance can be influenced by the gas flow and material properties. Hence, the influence of gas flow on the cell performance was conducted to analyze the electron transfer path. The stack repeating units 3 and 5, 4 and 6, and 7 and 8 had the same gas flow channel with a strip space of 2.4, 3.6, and $6 \mathrm{~mm}$, respectively. Fig. 3c) shows the 
difference in power densities between stack repeating units 3, 5, and 7 under various gas flow rates. The cathode side of these stack repeating units was completely covered with the Ag paste. Thus, the effects of cathode current collector of these three stack repeating units on the stack performance could be considered identical. Accordingly, the difference in power densities can be attributed to the effect of gas flow rates.
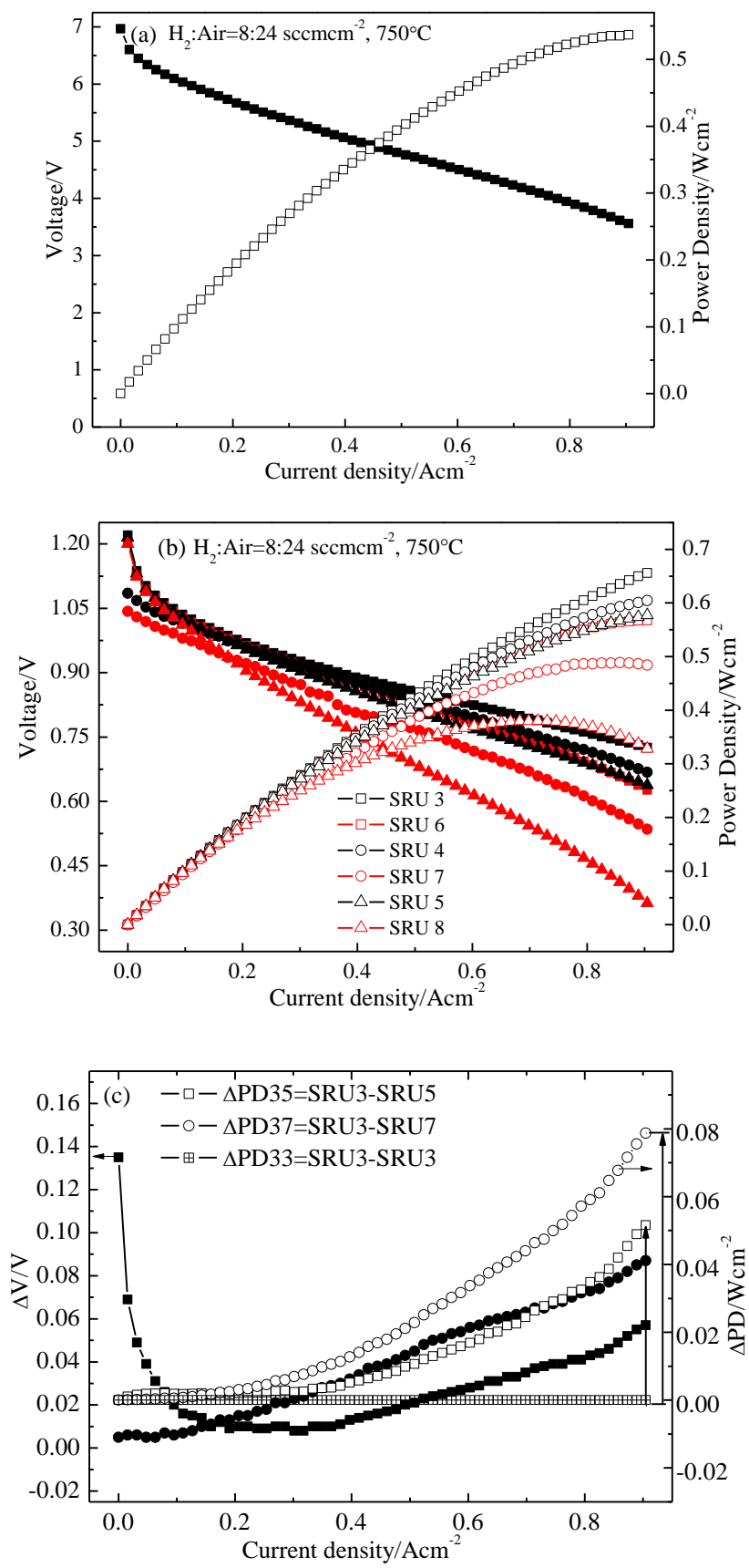

Fig. 3. I-V curves of stack 2 (a) and its corresponding repeating units (b), and their differences in cell voltage $(\Delta \mathrm{V} / \mathrm{V})$ and power density $(\Delta \mathrm{PD})$ between different stack repeating units measured under various gas flow rates (c). 

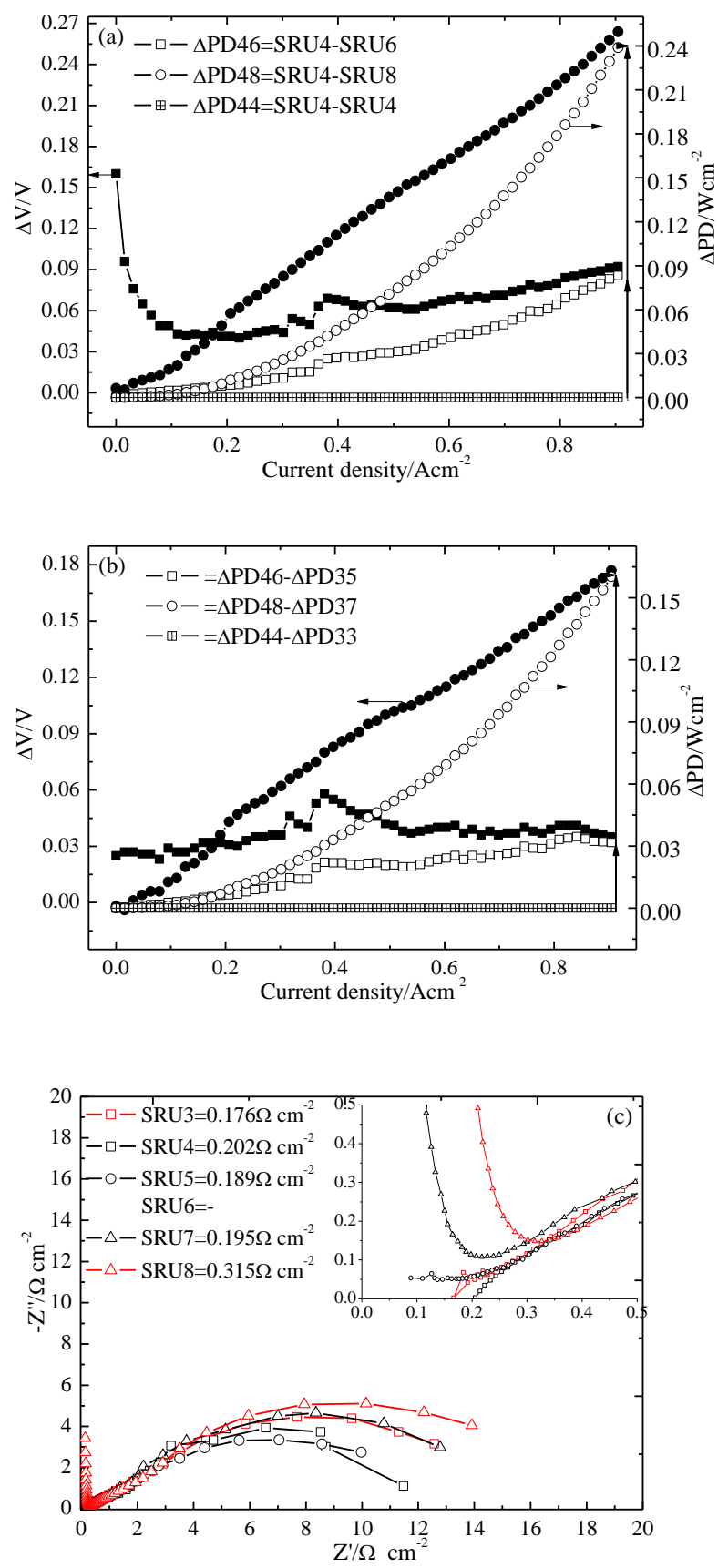

Fig. 4. Analysis of the differences in power densities for both the gas flow and in-plane electron transfer (a), on in-plane electron transfer (b) and EIS of various stack repeating units in stack 2 (c).

Fig. 4a) shows the difference in power densities of stack repeating units 4,6 , and 8 . The cathodes of these three stack repeating units were partially covered by Ag paste at the position in contact with the interconnect strips with a spacing of 2,3 , and $5 \mathrm{~mm}$, respectively. 
Therefore, the performance difference is due to the influence of both gas flow and in-plane electron transfer. The value shown in Fig. 4a) was much higher than that indicated in Fig. 3c) at the same current discharge. If the value shown in Fig. 4a) is subtracted by those shown in Fig. 3c) at the same discharging current, the results will show the impact of in-plane resistance on the power density (Fig. 4b), which plays a much greater role than the gas flow rate.

Fig. 4c) presents the EIS curves of various components in stack 2 under OCV conditions. The results showed that the ohmic resistances of stack repeating units 3 to 8 were 0.176 , $0.202,0.189,-, 0.195$, and $0.315 \Omega \mathrm{cm}^{-2}$, corresponding to a polarization resistance of $16.38,13.32,15.12,-, 17.01$, and $18.27 \Omega \mathrm{cm}^{-2}$, respectively. It shows that the values of electrode polarization resistance are rather high, while the peak power density of unit cells still can reach to about $0.66 \mathrm{Wcm}^{-2}$. It is verified again that the cell performance was determined mainly by the ohmic resistance, which is strongly related to the cell electrolyte and its interface contacting with electrodes from literatures [34-35]. The difference in power densities of stack repeating units 4,6 , and 8 was due to the variations in both ohmic and polarization resistances, attributed to the difference in electron transfer resistance and gas flow rates. The in-plane electron transfer will take place if the cathode thickness is uneven. Although the value of in-plane voltage is relatively smaller than that of longitudinal voltage, the cumulative effect of in-plane electron transfer resistance cannot be ignored. Therefore, it is possible to improve current collection efficiency by designing contact structures mainly because of better electron transfer path or collection of in-plane electron at the interface.

\section{Conclusions}

A stack was assembled with two pieces of single cells with a size of $10 \mathrm{~cm} \times 10 \mathrm{~cm}$; one 
cell was completely covered with the Ag paste on the cathode side (single cell 1) and the other cell was partially coated with Ag paste on the cathode side at the corresponding position in contact with the punctuate structure of the interconnect (single cell 2). The stack was discharged under a given gas flow rate and a certain operating temperature. The results showed that the performance of the single cell \#1 was higher than that of cell \#2. The difference in power densities between the two single cells was mainly due to the electron in-plane transfer on the cathode surface. The current-collecting effect of the cathode totally covered with Ag paste was much better than that of the cathode partially covered with $\mathrm{Ag}$ paste. The second stack was assembled and examined. We found that the cell performance was influenced by both gas flow and in-plane electron transfer. The effect of electron in-plane transfer on cell performance was more significant than that of gas flow rate. Therefore, the cumulative effect of the in-plane electron cannot be neglected. An appropriate arrangement of electronic collection at the cathode side should be designed to improve current collection and thus the cell performance inside the SOFC stack.

\section{Acknowledgments}

The author would like to thank the financial support from Natural Science Foundation of China (No.51502316), China Scholarship Council and Youth Innovation Promotion Association CAS. The work was partially supported by US DOE through DE-FE0026097.

\section{References}

[1]E.D. Wachsman, C.A. Marlowe and K.T. Lee, Energy Environ. Sci. 5(2012) 5498-5509.

[2]T.L. Wen, D. Wang, M. Chen, H. Tu, Z. Lu, Z. Zhang, H. Nie, W. Huang, Solid State Ionics 148(2002)513-519.

[3]T.L. Wen, D. Wang, H.Y. Tu, M. Chen, Z. Lu, Z. Zhang, H. Nie, W. Huang, Solid State Ionics 152-153(2002)399-404.

[4]H.Y. Jung, S.H. Choi, H. Kim, J.W. Son, J. Kim, H.W. Lee, J.H. Lee, J. Power Sources 159(2006)478-483. 
[5]S. Choi, S. Yoo, J. Kim, S. Park, A. Jun, S. Sengodan, J. Kim, H.Y. Jeong, Y.M. Choi, G. Kim, M.L. Liu, Scientific Reports, 2013(3)2426.

[6] E. Stefan, G. Tsekouras, John T.S. Irvine, Adv. Energ. Mater.3 (2013)1454-1462.

[7]S. Cho, D.E. Fowler, E.C. Miller, J. Scott Cronin, K.R. Poeppelmeier, S.A. Barnett, Energy Environ. Sci.6 (2013)1850-1857.

[8]R. Martínez-Coronado, J.A. Alonso, M.T. Fernández-Díaz, J. Power Sources 258(2014)76-82.

[9] C.S. Ding, T. Hashida, Energy Environ. Sci.3 (2010)1729-1731.

[10]L. Dieterle, P. Bockstaller, D.Gerthsen, J. Hayd, E. Ivers-Tiffée, U.Guntow, Adv. Energ. Mater.1 (2011)249-258.

[11] S.P. Jiang, Int. J. Hydrogen Energy 37(2012)449-470.

[12]A. Mai, B. Iwanschitz, U. Weissen, R. Denzler, D. Haberstock, V. Nerlich, J.A. Schuler, ECS Trans. 35(2011)87-95.

[13]B. Groß, L. Blum, L.G.J. de Haart, A. Dengel, J. Power Sources 196(2011)5309-5316.

[14]P. Narasimhamurthy, R. Kerr, 12 ${ }^{\text {th }}$ Annual SECA Workshop, Pittsburgh, PA, 2011.

[15]N. Christiansen, H.H. Larsen, S. Primdahl, M. Wandel, S. Ramousse, A. Hagen, ECS Trans.35(2011)71-80.

[16]W. Wu, W.B. Guan, G.L. Wang, Y.F. Zheng, W.G. Wang, Fuel Cells 13(2013)743-750.

[17] W.B. Guan, H.J. Zhai, L. Jin, T.S. Li, W.G. Wang, Fuel Cells 11(2011)445-450.

[18] S.P. Jiang, J.G. Love, L. Apateanu, Solid State Ionics 160(2003)15-26.

[19]A. Morán-Ruiz, K. Vidal, A. Larrañaga, M.I. Arriortua, Fuel Cells 13(2013)398-403.

[20]H.T. Lim, S.C. Hwang, M.G. Jung, H.W. Park, M.Y. Park, S.S. Lee, Y.G. Jung, Fuel Cells 13(2013)712-719.

[21] M. Mori, Y. Liu, T. Itoh, J. Electrochem. Soc. 156(2009) B1182-B1187.

[22]K. Channa R. De Silva, B.J. Kaseman, D.J. Bayless, Int. J. Hydrogen Energy 36(2011)779-786.

[23] H.P. Ding, X.J. Xue, RSC Advances 4(2014)11317-11321.

[24] S.X. Liu, C. Song, Z.J. Lin, J. Power Sources 183(2008)214-225.

[25]L. Jin, W.B. Guan, J.Q. Niu, X. Ma, W.G. Wang, J. Power Sources 240(2013) 796-805.

[26]V. Brichzin, J. Fleig, H.U. Habermeier, G. Cristiani, J. Maier, Solid State Ionics 
$152-153(2002) 499-507$.

[27] R. Das, D. Mebane, E. Koep, M.L. Liu, Solid State Ionics 178(2007)249-252.

[28] M.E. Lynch, M.L. Liu, J. Power Sources 195(2010)5155-5166.

[29]W. Wu, W.B. Guan, W.G. Wang, J. Power Sources 279(2015) 540-548.

[30] W. Wu, W.B. Guan, G.L. Wang, W.G. Wang, Adv. Energ. Mater. 4(2014) 1400120(8).

[31]L. Jin, W.B. Guan, X. Ma, H.J. Zhai, W.G. Wang, J. Power Sources 253(2014) 305-314.

[32]W.B. Guan, L. Jin, W. Wu, Y.F. Zheng, G.L. Wang, W.G. Wang, J. Power Sources 245(2014)119-128.

[33] R. M. Ormerod, Chem. Soc. Rev.32 (2003)17-28.

[34] X.D. Wang, W.B. Guan, R. Yu, W. Liu, W.L. Pei, X.D. Zhou, Int. J. Hydrog. Energ. 41(2016)22337-22343.

[35] T. Matsui, M. Komoto, H. Muroyama, K. Kishida, H. Inui, K. Eguchi, J. Power Sources, $312(2016) 80-85$. 


\section{List of Figures and Table captions}

Fig. 1. Schematics of single cell and interconnect. (a) Cathode was completely covered with the Ag paste, (b) cathode was partially covered with Ag paste, (c) A schematic of the interconnect, (d) Interconnect with strips and (e) A single cell covered with Ag strips, and (f) A top surface image of the LSFC-based single cell covered with Ag paste showing the width of Ag strips and width of the parameter $\mathrm{H}$.

Fig. 2. $I$ - $V$, EIS curves of stack repeating units of the stack 1 and optical images of the boundaries for the cathode current collector of single cells 1 and 2. (a) I-V curves, (b) Single cell 1 (completely covered with $\mathrm{Ag}$ ) and (c) Single cell 2 (partially covered with Ag) and (d) EIS spectra of stack repeating units 1 and 2 of stack 1 .

Fig. 3. I-V curves of stack 2 (a) and its corresponding repeating units (b), and their differences in cell voltage $(\Delta \mathrm{V} / \mathrm{V})$ and power density $(\Delta \mathrm{PD})$ between different stack repeating units measured under various gas flow rates (c).

Fig. 4. Analysis of the differences in power densities for both the gas flow and in-plane electron transfer (a), on in-plane electron transfer (b) and EIS of various stack repeating units in stack 2 (c).

Table I. A list of all cell parameters and the stacks studied in this work 
Table 1 Parameters of various cells and its corresponding stacks

\begin{tabular}{|c|c|c|c|c|c|}
\hline \multirow{2}{*}{ Cells } & \multirow{2}{*}{ Stack } & \multirow{2}{*}{$\begin{array}{l}\text { Interconnect } \\
\text { surface }\end{array}$} & \multicolumn{2}{|c|}{ Designed spacing } & \multirow{2}{*}{$\begin{array}{l}\text { Ag covering on cell } \\
\text { cathode }\end{array}$} \\
\hline & & & Anode side & Cathode side & \\
\hline Cell 1 & \multirow{2}{*}{ Stack1 } & Square(Point) & $4.0 \mathrm{~mm} \times 4.0 \mathrm{~mm}$ & $4.0 \mathrm{~mm} \times 4.0 \mathrm{~mm}$ & Totally \\
\hline Cell2 & & Square(Point) & $4.0 \mathrm{~mm} \times 4.0 \mathrm{~mm}$ & $4.0 \mathrm{~mm} \times 4.0 \mathrm{~mm}$ & Partially \\
\hline Cell3 & \multirow{6}{*}{ Stack2 } & Strips & $2.4 \mathrm{~mm}$ & $2.4 \mathrm{~mm}$ & Totally \\
\hline Cell4 & & Strips & $3.6 \mathrm{~mm}$ & $2.4 \mathrm{~mm}$ & Totally \\
\hline Cell5 & & Strips & $6.0 \mathrm{~mm}$ & $2.4 \mathrm{~mm}$ & Totally \\
\hline Cell6 & & Strips & $2.4 \mathrm{~mm}$ & $2.4 \mathrm{~mm}$ & Partially \\
\hline Cell7 & & Strips & $3.6 \mathrm{~mm}$ & $2.4 \mathrm{~mm}$ & Partially \\
\hline Cell8 & & Strips & $6.0 \mathrm{~mm}$ & $2.4 \mathrm{~mm}$ & Partially \\
\hline
\end{tabular}

